State action to concern itself too much with the commercial aspect of tree-planting. Afforestation has been almost entirely directed towards the establishment of short term 'crops' of trees and not to permanent woodlands adapted to satisfy demands for amenity, recreation and protection. In harmony with this tendency special fiscal concessions are given to private woodland owners who engage in commercial forestry. Taxation, in relation to treeplanting in Britain, is not easy to understand, more especially as the tree grower is also entitled to certain grants in aid. The Government takes with one hand and gives with the other, and it is not very clear why. A case can be made for State assistance to recreate forests, and a case can be made for a simple single basis of taxation of commercial forests, namely, on the profits of the enterprise instead of on the timber capital; but it is extremely difficult to segregate the commercial forest from the amenity woodland and to say how the State should act in relation to the latter. The ideal woodland is that which fulfils the triple functions of protection, amenity and production, and many landowners could teach the Forestry Commission a lesson to that effect.

The fiscal concessions allowed to tr $\ni \theta$-growers have led to a striking and relatively recent development in forestry circles. Commercial afforestation enterprises have been set up and have become especially active in southern England and Wales. The task which they have set themselves would not be finan. cially attractive-it would not be economic--without the subsidies and fiscal concessions at present allowed. How successful these afforestation enterprises will be eventually, that is in the establishment of healthy permanent woodland, remains to be seen. Like the greater part of the Forestry Commission plantations they are, taking the long view, still experimental. If they pay the entrepreneurs it is solely because of the State assistance and taxation reliefs.

The position in respect of subsidies for treeplanting and of taxation relief to woodland owners certainly requires to be reconsidered; but whether it is desirable to give the Standing Committee on National Parks over-riding control on afforestation in such a way as to conflict with the duties of the Forestry Commission, or in any other way, is very doubtful.

The case for establishing such a control is put in a memorandum distributed by the Standing Committee on National Parks of the Council for the Preservation of Rural England and Wales and the Joint Action Group for the Protection of Dartmoor and Exmoor. They view with alarm the incursion of commercial afforestation into the Dartmoor and Exmoor National Parks in particular. They have a case. The solution does not lie, however, in resisting such encroachments but in trying to ensure that the State assistance on which the intruders depend is devoted to the creation of a type of forest which increases the amenities of the Parks while at the same time being productive.

There is no raason why the creation of these woodlands should result in the "squandering of any noble heritage of beauty" except in so far as tho mothods adopted are inappropriate. It is unfortunate that until recently State forest policy had subordinated too much the important protective and amenity functions of woodlands to the purely commercial function of producing timber, because it has placed the Forestry Commission in a weak position when it comes to discussing the best use of treeplanting associated with national parks.

In respect of Britain as a whole there are many districts where an afforestation policy of this kind would be welcomed, and which might benefit greatly from what is in effect the local expenditure of taxation revenues indirectly through the medium of private enterprise. Whether this is really a healthy development from the point of view of forestry is another matter. The production of figures in a book is a very different skill from that of creating and conserving a forest on the ground.

M. L. Anderson

\title{
PARENTS' VIEWS ON EDUCATION
}

D URING the past three years Political and Economic Planning has been carrying out an inquiry to determine how far the social services are meeting the needs of the people who use them.

Of the social services none can affect the life of the individual and the nation more radically than education, and, as a preliminary to a fuller report to be published later, Political and Economic Planning has produced a broadsheet recording the findings of the inquiry on the education service*. Since the object of the survey was to present the consumers' view of the social services, the broadsheet's approach to the education service must necessarily be a limited one. Parents' wishes cannot be equated with educational need. Parents may over-rate their children's abilities, or they may not understand what the school is trying to do. Nevertheless, it is part of the new plan for education that the parent should become more closely involved in the child's schooling. An understanding of parents' experience and opinions is, therefore,

* Planning, Vol. 27, No. 448 (January 23, 1961) : Parents' Views on Education. Pp. 1-32. (London : Political and Economic Planning, 1961.) 38. $6 \dot{d}$. essential when considering the present achievements of the education service.

The main inquiry was carried out among families living in the Greater London area. It had been decided that the inquiry must be concentrated in one district and that the locality chosen should be a large urban area since this is the type of community in which most people live. It should also be large enough to contain a diverse population and to include several local authority areas with a variety of different arrangements for some of the social services. Greater London fulfilled all these requirements. To make sure, however, that the findings for London were not untypical of the rest of Britain, a second smaller inquiry was carried out in Northampton, a provincial town of quite different size. This second inquiry confirms that the London findings can be con. sidered representative. A total of 734 families was successfully interviewed in the main inquiry. Since the social services to-day are not primarily concerned with hardship, or important only to limited sections of the population, it had been decided to study samples of all families with children under the age of 16 . 
It is evident from the answers received during the survey that there is now considerable interest in education and appreciation of its possibilities. The mothers showed concern with the kind of school attended by their children, and they had often decided that there was some particular form of higher education or specific training that they would like their children to have. A high proportion of those with older children said that they wanted them to stay at school after they were fifteen. Although interest was greatest at the top of the occupational scale, it was also strong among the operative groups. It would appear that the attitude towards education at all levels of society is becoming more positive. A higher standard of living together with smaller families has lessened the necessity for working-class parents to turn the child into a wage-earner as soon as possible. Instead, there is a wider realization that educational qualifications may be a valuable investment and that very wide opportunities may be open to the talented child. The old grudging attitude towards the school as a place in which children were detained when they might usefully have been out at work appears to be dying.

Although the prevailing attitude towards the education service is not an unfavourable one, there is a substantial section of unsatisfied demand for particular schools. There was no intention during the inquiry to set up arbitrary standards in the field of education and to test whether or not these were reached in the families in the sample. Nevertheless, it was a general principle in the Education Act that parents should be able to get the kinds of schools and education for their children that they think the children need. Altogether 17 per cent of the mothers in the inquiry said that they had failed to get particular types of school that they had wanted. Six per cent were thinking of nursery schools and 7 per cent of secondary schools (mainly grammar and technical). There may be differing views on whether or not there is a real need for these services as distinct from a demand for them; the need for expansion and improvement in these two fields has already been accepted by the community and incorporated in the Education Act of 1944. While the proportions of present-dey demand are small in comparison with the total sample, they are considerable when compared with the proportions who had used the types of school in question. (Five per cent of the families had used nursery schools, 12 per cent grammar schools and 6 per cent technical schools.)

The demand for grammar and technical schools and also, in some cases, the use of private schools, appears to be the result of parents' dissatisfaction with secondary modern schools. Some of their comments suggest that they regard the secondary modern school as offering inferior academic education and as not providing a specific onough training for a particular job. If the objects of the 1944 Education Act are fully realized and secondary modern schools come to be recognized as enjoying the equality of facilities and staffing with grammar schools, it seems possible that the demand for grammar schools may decrease. Similarly, if secondary modern schools play their part in the provision of technical education then parents are less likely to feel that their children are missing opportunities for occupational training. The present situation, in which certain secondary schools are obviously considered superior to others, is socially undesirable and harmful to the successful as well as the unsuccessful children.

It is important, however, that parents should be able to arrange for a grammar school place for those children who should benefit from it. One feature that emerges from the Political and Economic Planning survey is that at present the education service is being used most advantageously by families at the top of the social scale. The managerial and professional group and the supervisory and technical group have been more successful than others in obtaining grammar school places for their children. It is the managerial and and professional group that shows the strongest awareness of education.

The desire for further information is strong among the other groups, however, and the disparate use of the service cannot be entirely accounted for by less interest in education among these groups. When parents at the bottom of the occupational scale would prefer a grammar school place for their children they are, nevertheless, less likely to obtain it. It seems that there are a number of parents failing to get the education they would like for their children because the education itself is beyond their own experience.

The demands which parents make on the education service on behalf of their children may sometimes be unreasonable or because they are inadequately informed. On one hand, parents may identify their own social prestige too closely with their children's achievements or, on the other hand, they may be too little aware of the ends and means of education. It appears, for example, that the mothers questioned in the survey were concerned predominantly with the jobs their children would get and not with the enrichment of their personality. Nevertheless, it is important that parents should feel reasonably satisfied with their children's education.

\title{
TERRESTRIAL SPECTROSCOPY
}

\author{
By Frof. C. L. PEKERIS, Z. ALTERMAN and H. JAROSCH \\ Department of Applied Mathematics, The Weizmann Institute, Rehovot, Israel
}

$\mathrm{T}$ THE discovery of the Zeeman effect in 1896 came at a time when the basic concepts needed for its interpretation had been worked out by Lorentz ${ }^{1}$. Already in his first paper ${ }^{2}$, Zeeman reported a verification of the polarization of the lines, an effect which Lorentz had advised him to look for. He gives a derivation, on the basis of the Lorentz theory, of the formula for the splitting of the original frequency $\sigma_{0}$ by a magnetic field $H$ :

$$
\sigma=\sigma_{0} \pm \frac{e H}{2 m c}
$$

This relation had been derived independently by Larmor. Larmor proved ${ }^{3}$ that the effect of a mag- 